\title{
SWOT Analysis on the Cultivation of Design Talents in Chinese Higher Education
}

\author{
Shaolin $\mathrm{Xu}$ \\ Cheng Kong School of Journalism and Communication \\ Shantou University \\ Shantou, China
}

\author{
Ruohong Fang* \\ Cheng Kong School of Art and Design \\ Shantou University \\ Shantou, China \\ *Corresponding Author
}

\begin{abstract}
Cultural creative industry is the commanding height of national soft power competition in 21 st century and the important fountain of alteration of Chinese economic development and transformation of city development. The core of cultural creative industry is innovative talents, and as a midst link of culture creativity industrial chain, design education bears the heavy responsibility of cultivating innovative and applied talents. In this article, it analyzes the current situation of design talents in universities and colleges under the background of Chinese cultural creative industry by virtue of SWOT analysis method and provides suggestions and strategies on the cultivation of innovation-oriented design talents.
\end{abstract}

Keywords-design; talent cultivation; creativity education; originality

\section{INTRODUCTION}

In 2006, the State Council issued the Culture Development Program during the National 11th Five-Year Plan Period, in which it puts forward the "cultural creative industry" and marks that cultural creative industry has become an important emerging industry in the development of Chinese economy. "From 2005 to 2011, the annual average growth of Chinese cultural creative industry is $23 \%, 6.6 \%$ higher than GDP in corresponding period. While from 2004 to 2013, the proportion of value added in GDP occupies rises from $1.94 \%$ to $3.77 \%$, and it realized value added of 2.1 trillion yuan in 2013." [1] The growth momentum of cultural creative industry is rapid and becomes the important fountain of alteration of Chinese economic development and transformation of city development. Cultural creative industry is the commanding height of national soft power competition in 21st century. And the core of cultural creative industry is innovative talents, and innovative ability is a special ability, which requires talent and acquired cultivation, it cannot be acquired through simple training nor grafted by other professional talents. The traditional exam-oriented education pays little attention on the innovative thoughts of students, which is not good for talent showing itself; hence, how to cultivate innovative talents has become an important issue studied in higher education. In this article, it analyzes the current situation of design talents in universities and colleges under the background of Chinese cultural creative industry and provides suggestions and strategies on the cultivation of innovation-oriented design talents by virtue of SWOT analysis method through four aspects of strength, weakness, opportunity and threat.

\section{SWOT ANALYSIS ON CULTIVATION OF DESIGN TALENTS IN UNIVERSITIES AND COLLEGES OF CHINA}

\section{A. Strength Analysis}

1) Chinese traditional culture of long standing: Chinese traditional culture is extensive and profound and the national cultural deposits are rich, which have an enormous influence on the modern design subject. Five thousand years ago, in Yangshao culture period, painted pottery had been come an artwork with era characteristics. It constitutes the traditional craft design course of Chinese people from the bronze vessel of Shang Dynasty and Zhou Dynasty to handcraft of Han Dynasty, from the world-famous "Tangsancai" to plain and elegant porcelain of Song Dynasty and from the Suzhou embroidery of Ming Dynasty to the furniture of Qing Dynasty. In regard to the drawing, handwriting, drama, architectural art and folk art of China, all of which show the cultural deposit of Chinese nation in thousands years. Hence, Chinese traditional will be the inexhaustible fountain-head of literary and artistic for designers and an important strength of cultivation of design talent as well.

2) Solid professional basic skill: Students in Chinese design major must pass the unified art skill examination of all provinces, generally including three subjects of drawing, color and sketch. The writer once investigated the training time of art before entering colleges in 421 undergraduates, and it indicates that before entering college, all of them have received professional art training, of which there are 46 students having training time of art for 1 year, occupying $11 \%$ of the totality; 105 students for 2 years, occupying $30 \%$ of the totality; 135 students for 3 years, occupying $32 \%$ of the totality; 66 students for 4 years, occupying $15.7 \%$ of the totality; 10 students for 10 years above, occupying $2 \%$. It reflects that students in Chinese design major have relatively solid professional basic skill. Most design majors establish professional basic courses of sketch, color, plane composition and space composition in the first year, which lays solid professional basis for the design creation in senior grades. 
3) Development of creativity education: Since the 1980's, universities and colleges have carried out creativity education actively. Many universities establish a series of courses on creativity thoughts and creativity; some of them establish undergraduate major of creation science; some carry out "creation salon" activities, organize to learn the principles and methods of creation science as well as conduct innovation test; some colleges set up creativity research center, implement research on theory and practice of creativity and drive the implementation of creativity education in each subject. And these theoretical and practical experiences become one of the strengths of cultivating innovation-oriented design talent.

\section{B. Weakness Analysis}

1) Lag of creativity education theory: The general practice of implementation of "creativity education" is to start from some related courses, which is behavior setting without originality. In nature, "creativity education" is a reform of education way and a cultivation of study and thought modes. The spirit and courage of independent thoughts, new channels and whimsicality, as well as the creative study ability, observation ability and thinking ability are specially required for creativity. Hence, if the stiff educational method, study mode and thinking mode are not changed, then let "creativity education" alone.

2) Excessively independent subject and courses lacking of internal connection: Teaching "design" as a complete independent subject is a misunderstanding of teaching conception firstly, which derives from the narrow-minded ideology and understanding of "design". And this misunderstanding is concretely embodied at the curriculum provision, such as, besides public compulsories of English and ideology and politics in most art and design colleges, most of the rest are highly independent design curriculum. Lacking of humanity courses and interdisciplinary courses as well as effective connection among some professional courses may directly influence students on the integral grasp of design.

3) Infuse-teaching mode is not good for cultivation of students' creativity: The process of traditional design teaching mainly is based on infuse-teaching mode of teachers, which results in students lack of desire of active learning and lose their ability of actively discovering problems and further solving problems; generally, it requires students completing homework as specific mode and for students per se, they cope with homework for completing task, so that their works lack of originality and have strong imitation feeling. By contrast, it adopts brainstorm type and discussion type teaching mode in design teaching in foreign countries, hence, the task becomes a free space for students giving full play to originality, which can stimulate the students' activity and creativity.

4) Blind worship and imitation of western design: Many designers advocate western design very much, even imitate western design since the reform and opening-up of China. Nevertheless, "observe the style of European design in detail, it is not difficult to find that while designers exhibit their originalities, they happen to coincide remaining the sense of manual operation. Perhaps it's because the designers inherit the craftsman working way which becomes one of their design consciousness finally." [2] At present, the application of Chinese traditional cultural art in design is relatively weak wholly, far from acquiring deserved attention in design education. Chinese design is unfamiliar with and unable to rein its mainland traditional art, which is other important reason causing thin design language of modern China.

\section{Opportunity Analysis}

1) The demands of nation for cultural creative industry drives the cultivation of creative talents: With the speed-up promotion of economic globalization, in the competition of comprehensive national strength of 21 st century, the function of cultural creative industry become more and more obvious. As of 2002, China had started the medium \& long term scitech development program, converting from the advance gradually development model pursuing tracking, learning and imitation for over 20 years after the reform and opening-up to the great-leap-forward development of self-dependent innovation, which requires the cultural art, radio, film, television and media industries of China converts from imitatively study to self-dependent innovation technically. In 2014, the State Council issued the Several Advises on Promoting the Integrative Development of Cultural Consciousness and Design Services with Related Industries ${ }^{[3]}$, in which, it indicates the booming development of cultural creative industry provides powerful policy security and behavior support for universities cultivating innovationoriented talents, and it not only indicates the development direction of trend of design major, but also provides new thoughts for design teaching innovation, stimulate the combination of design major teaching and platform of cultural creative industry, so as to speed up driving the progress of cultivating innovation-oriented and applied talents and transporting more innovation-oriented talents for our society.

2) Continuously strengthen university-industry cooperation: In recent years, universities grasp the demands of enterprises for talent structure and skill upgrading through cooperation with local advantage enterprises. Through cooperation, the universities increase some exploratory subjects consciously combining some forward-looking subjects with the concrete items in our society, so as to realize the integration of production, study and research. Meanwhile, it fully utilizes the university-industry practice base, make students master the basic methods of design organization and project management through practice, as well as make the students get closer to the market and society and increase their practical abilities. It is understood from the said that, strengthening the university-industry cooperation not only provides practice opportunity but also mobilize the internal impetus of student creativity.

3) Inheritance and innovation of traditional culture: Culture is the spirit and soul of a nation, and the inheritance 
and innovation of traditional culture are good for the development of design. Entering the 21 st century, our country joined in the Convention for the Safeguarding of the Intangible Cultural Heritage of UNESCO, the "Project of Protecting the National Folk Literature" started and carried out, meanwhile, it confirms June 9 as national culture heritage day in 2005. In recent years, Chinese knot, Tang suit, Cheongsam and traditional festival reflect the pursuit and worship of masses to traditional culture in other perspective. The promotion and encourage of the nation and masses in traditional culture and innovation provide favorable humanistic environment and society atmosphere.

\section{Analysis of Challenge}

1) Lack of innovation-oriented teacher strength: "Creativity education" needs teachers with innovation spirit and ability firstly before cultivating creative students. In nature, "creative education" is a reform of education way, hence the first education objective of "creativity education" is teacher. To cultivate students' innovation thoughts and ability as well as establish new learning style and thinking style, it requires teachers having relevant innovative thoughts, ability and quality to "creativity education", so that they can better educate students how to convert thoughts, explore thoughts and analyze and solve problems through critical thinking and creative thinking. From the perspective of the teacher team's education background and teaching situation in current China, it lacks of innovation-oriented teachers; hence, cultivating innovation-oriented teachers is a relatively hard work.

2) Narrow space for creativity: "Creativity education" is a space problem instead of a time problem, that is to say how large space for us to develop "creativity education" under our current educational system and social environment. "Creativity education" specially requires for space, particularly the space of conception and system. Big space is corresponding to high inclusiveness, so that it can contain various unusual but wonderful thinking, even uncharacteristically disruptive conception. There is also a problem of spatial purification in "creativity education", if repeated design at low level even duplicate design occupies too much space, the sprout of creativity will stifle, successively the severe desertification will appear in the creativity garden. It is a severe challenge for China to change the narrow creativity space formed under the traditional exam-oriented education and imitation development strategy for long term.

3) Short of creativity culture atmosphere: A cultural atmosphere is required for creativity, such as, library, museum, gallery and other cultural facilities, creation competition and activity, customs and languages all can build the creation atmosphere of creativity of living and life of creativity. In China, both hardware and software facilities are not enough to build a favorable creativity atmosphere. Such as, the American teacher or parents may ask that "What's new?" "Is anything interesting?", while British would like to ask
"What's novel?", but the Chinese parents and teachers often ask "What's your rank?" "Obedient or not?" and "See others how to make it".

\section{BREAK THROUGH THE BOTTLENECK-SUGGESTIONS FOR CUltivation of Design TALENTS IN CHINESE UNIVERSITIES AND COLLEGES}

\section{A. Remodeling the Cultivation Idea of Design Talents}

In order to cultivate design talents with innovative consciousness and ability, it must solve the current situations of too much attention on skills and lack of cultivation of thinking ability in traditional design education. Therefore, we advocate focusing on humanity contacting to enlighten personal creative thoughts and remodel the cultivation idea of design talents: (1). Based on Chinese culture, introduce international experiences, construct design major with Chinese characteristics and cultivate innovation-oriented professional talents; (2). integrated with enlightened creativity, major and humanistic spirit, cultivate the personal view and quality development of teachers and students; (3). take the merging of "heart and hand" as teaching guideline, focus on the grasp of practice and professional skills; encourage students to integrate the creativity into life and stimulate selfpotential and cultivate their artistic culture; (4). broaden students' international view through inter-media and interculture academic exchange activities; (5). cultivate the independent thinking and critical thinking ability of students and develop them the habit of continuous self-assessment and self-improvement as their impetus of lifelong learning.

\section{B. Constructing Design Curriculum System with Chinese Characteristics}

Curriculum is the core to realize talent cultivation, and it requires advocating "Chinese style design" based on Chinese culture and introduce the international professional knowledge and essences into mainland teaching, exploring new approaches supported by design as core and involved in cultural creative industry, as well as establishing modern design curriculum with Chinese characteristics. And the curriculum provision takes emphasizing training of creativity and improving the Chinese culture cultivation and students' practice ability as purpose. The subject combination includes: vision and originality theoretical basis course (providing basis training of design and art, emphasizing the cultivation and play of originality ability so as to reach creation status of "heart and hand"); design art special course (integrating the learned in forms of workshop and develop into experimental works, so as to reach enter-connection of curriculums and strengthen the teaching effect on the students' design and application ability);Chinese culture and art course (paying more attention on the education and edification of Chinese traditional culture, folk art and modern culture art); evaluation and analysis on Chinese and Western culture value (providing analysis and discussion on the design works of China and west for students understand the cultural characteristics of China and west countries, so as to inherit innovative approaches from different entry points); general education curriculum (playing the advantage of multidisciplinary of comprehensive university, operating credit system platform, 
breaking through the subject barrier, encouraging students to select subjects of other schools, such as marketing, management, customer praxiology, customer relationship management, public relations planning, communication sciences, media management etc. and driving the integration of humanistic education, science education and specialty education).

\section{Carrying out International Exchange Activities and Exploring the International View of Students}

Actively create conditions, hold international academic activities, construct inter-culture art exchange platform and build international academic atmosphere. Invite art creators and professional designers devoting themselves to different cultural creative industries from all over the world holding lectures and workshops, sharing their experiences and practical cases, so that the students can master the latest design development trend, open their international view, so as to enlighten their originality thoughts and burst out the enthusiasm of creation deep down. In addition, establish cooperation partnership relationship with foreign art design institution, carry out exchange program and related research projects and promote the inter-culture exchange and research cooperation among universities and colleges.

\section{Formation of Campus Culture Emphasizing Practice and Innovation}

Burton R. Clark, the American famous educator, raised the conception of "Entrepreneurial Universities" early in 1998, which refers to the university of self-leading and self-reliance, emphasizing looking forward, the desire of exploring advanced knowledge and seizing unqualified opportunity with great efforts. To cultivate students' innovation ability, we need to construct corresponding "innovation-oriented college", form favorable innovative culture and new atmosphere, as well as introduce students entering the innovative design field as soon as possible. Guide students to participate in various professional competitions in and around the school, build platforms for students to exhibit their originalities and design results through holding art design professional competition, curriculum works exhibition and graduation thesis exhibition independently and cooperating with other colleges. Exhibit students' art and design works in campus environment, explore the methods of modeling overall style and forms of campus landscape art as well as the university cultural brand image, so as to encourage more students to participate in the construction of campus environment.

\section{E. Exploration of Design Integrated Production, Learning and Research}

Only design education corresponds to the development of social production, establishes more direct and closer relationship with economy and science as well as further cooperation with enterprise and industry departments can the aspects of cultivation, curriculum provision and subject construction of design talents fully take the practical demand of society into consideration. Firstly, strengthen the design of applied project in teaching and actively organize students to participate in social practical projects, so as to make organic combination of the design ability of students and market demand. Consciously combine some forward-looking issues with concrete projects in teaching, gradually cultivate students' self-organization ability in learning process, develop their innovative potential and transform imitativeness design to innovative design. Secondly, carry out university-industry cooperation, strengthen the cooperation with local strength enterprises, understand the demands of enterprises for talent structure and technology, provide technical support for selfdependent innovation and industry upgrading of enterprises, well manage to technical innovation and talent cultivation and serve the local economic construction. Meanwhile, fully utilize the university-industry practice base, make students be familiar with the design process through practice, and master the project management, basic methods of enterprise organization management and strengthen their practical abilities. At last, establish the design research center. Combining with the power of production, learning and research, promote development of talents exchange, design specialization and Chinese originality industry. Fully utilize the network and talent resources, assist domestic enterprises create self-dependent brand of "Made in China". The research center can hold training project on a regular basis, carry out strategic research projects as well as provide consulting services for the enterprises and government.

\section{CONCLUSION}

China is in the booming development stage of cultural creative industry, while the art, films and televisions as well as media the cultural creative industry covering are inseparable with design. As the middle link of cultural creative industry chains, design education bears the responsibilities of cultivating innovation-oriented and applied talents. In particular, under the background of cultural creative industry, the development of design specialty needs to combine the practical demands of the development of local society and economy, and only through continuous innovation exploration of specialty teaching can it provide a steady flow of originality sources and storage of high-qualified innovative talents for the cultural creative industry in the future, so that it can drive the progress of our society and the development of economy, as well as realize win-win of university and talent cultivation.

\section{REFERENCES}

[1] Yang Yunyan, Zhengyi: "The General Situation of Cultural Creative Industry Development in China", Times Finance, stage 6 of 2014, page 155 .

[2] [Japan] Hara Kenya: Design of Design (Chinese version), translated by Zhu e, Shandong people's publishing house, 2006, page 28.

[3] Several Advises on Promoting the Integrative Development of Cultural Consciousness and Design Services with Related Industries, March 14, 2014,http://www.gov.cn/zhengce/content/2014-03/14/content_8713.htm. 